\title{
The Effect of Chorus Education in Disadvantageous Groups on the Process of General Education-Cultural Awareness and Socializing: The Sample of Gypsy Children
}

\author{
Gülnihal Gül ${ }^{1} \&$ Bilgehan Eren ${ }^{2}$ \\ ${ }^{1}$ Department of Music Education, Uludag University, Bursa, Turkey \\ ${ }^{2}$ Department of Special Education, Uludag University, Bursa, Turkey \\ Correspondence: Gülnihal Gül, Department of Music Education, Uludag University, Bursa, Turkey. E-mail: \\ gulnihalgul@gmail.com
}

Received: August 18, 2017

Accepted: October 12, 2017

Online Published: October 16, 2017

doi:10.5539/jel.v7n1p125

URL: https://doi.org/10.5539/jel.v7n1p125

This study registered as OUAP2015/16 and supported by the Scientific Research Projects Unit of Uludag Univesity.

\begin{abstract}
Many reasons such as social exclusion, economic insufficiency, and prejudice make it difficult for Gypsy children to reach qualified education and cause their expectations for the future to be minimized. Yet, it is considered that the property of "inclination to music", linked especially with Gypsies, will positively affect the motivations of Gypsy children for the school and their academic achievement and thus music education and chorus education performed in this context will make considerable contributions to the education process of the children.

In this context, with a pilot classroom selected from the $4^{\text {th }}$ grades in a primary school all of whose students consist of Gypsy children, chorus education studies have been carried out for an academic year. In accordance with the results obtained from the research, it has been reached the end of the fact that chorus education studies have made positive contributions to the general education, cultural awareness and socialization process of Gypsy children included in the disadvantageous groups and presenting Gypsy children with the opportunities that they can turn the music permanently present in their daily lives into an advantage in educational terms is quite important.
\end{abstract}

Keywords: disadvantageous group, gypsy children, chorus education

\section{Introduction}

The phenomenon of social exclusion, defined as individuals' or groups' partially or completely staying out of the society where they live in terms of spatial and social participation depending upon structural and personal realities or availing themselves of civil rights is a multi-dimensional "access" and "participation" problem including cultural, economic, social and political aspects such as cutting off ties with the labour market, not accessing services such as education and health and tarnishing social justice as a barrier in front of the access to equality of opportunity, social participation and services (Chakravarty, 2006; Akkan, Deniz, \& Ertan, 2011, p. 23; Hekimler, 2012, p. 4; Akkan, Deniz, \& Ertan, 2016, p. 116). The society hesitates over including disadvantageous groups under the risk of social exclusion and disadvantageous groups, due to their being exposed to social exclusion, have difficulty in adapting to the society, cannot get sufficient equipment and feel themselves insufficient (Genç, Taylan, \& Barış, 2015, p. 84). The disadvantage, resulting from physical disabilities, social value systems and being deprived of knowledge and skill that the labour market demands, can cause the individual to experience physical and social disabilities and encounter discrimination during employment market entrance, working life and dismissal (Alp, 2014, p. 1; Klasen, 2016).

One of the groups facing social exclusion and poverty in Turkey is by Gypsies having cultural norms different from the society. Gypsy emigration, considered to have started in India between $5^{\text {th }}$ and $9^{\text {th }}$ centuries, spread over Iran. It is accepted that Gypsies set foot in Anatolia over Syria and Armenia, they reached the east borders of 
Byzantine Empire in the beginning of $11^{\text {th }}$ century and they started to settle on the plateaus of Thrace from the first half of the $12^{\text {th }}$ century and it is known that they spent settled life in Thrace in the Ottoman Period. Gypsies having settled in Turkey in the context of population exchange with Greece in the Republic Period has a considerable place in the population of Turkey (Taylan \& Barış, 2015, p. 18; Uzpeder, Danova/Roussinova, Özçelik, \& Gökçen, 2008, p. 15; Ünaldı, 2012, p. 617).

Living mainly in Europe and Asia but existing in almost every part of the world, Gypsies are generally despised by the society they live in, called as swarthy citizen, drayman, copt, lom (Şener, 2006, pp. 230-237) and compared to the other sections of the society, they have considerable problems in accessing and utilizing civil rights, social acknowledgement, education, housing and employment (Genç, Taylan, \& Barış, 2015, p. 84).

Barry (1998) expresses that social inclusion such as to tarnish equality of opportunity in two respects as education and politics. Education is highly important to bring the individual in social participation and prestige. Yet, it is seen that disadvantageous groups, one of the most important factors affecting the development, cannot exactly avail themselves of education from their childhood years, become psychosocially excluded during their education and have difficulty in communicating with their surroundings (Cevizci et al., 2015, p. 40). In this context, Gypsies are the most leading groups experiencing the greatest social exclusion in terms of education in Turkey. Non-Gypsy families do not approve their children of having education with Gypsy children in the same institutions, and in this situation, Gypsy children attend the schools where only Gypsies have education and their social exclusion increases. In addition, it is observed that absence from school is at a high level among Gypsy children, there are illiterate ones even among children attending the fourth grade and the children go to seasonal work with their families having no regular income and thus they leave their education.

Many reasons such as social exclusion, economical insufficiencies and prejudice make it difficult for Gypsy children to reach qualified education and these reasons cause their expectations for the future to become minimised. Yet, it is considered that the property of "inclination to music" linked especially with Gypsies and their identity and statues they have due to their musicianship (Sağer \& Mustan Dönmez, 2012; Kılınçer \& Mustan Dönmez, 2013) will positively affect Gypsy children's motivations towards school, their school attendance and academic achievement and for that reason music education and in this context chorus education will make considerable contributions to the education process of Gypsy children.

Chorus education, the functions of which are centralised in five main sets as social, individual, cultural, economic and educational ones, is a specific whole within music education (Uçan, 2001, p. 35). Chorus education, being a basis mainly to voice training and having the target of bringing in the behaviours regarding correct voice production and using correct voice, in accordance with the main principles and aims of contemporary music education, aims for a common singing style to be established and popularized (Sökezoğlu, 2012, p. 259; Çevik, 2001, p. 67). In chorus education implemented in accordance with these aims, generally body softness and comfort, breath and voice training, singing education, audince and rhythm education and educations of acquiring music culture are realized (Türkmen, 2012, p. 277). In addition to general music education they have in the framework of chorus education, chorus members acquire the habit of working collectively by singing together, socialize by making friends, comprehend the necessity of democratic values in society and their self-confidence increases (Apaydın, 2001, p. 135).

Egüz (1981) expresses that music is one of the strongest social ties and ballads and songs are the ties making generations and even societies closing up to each other. For that reason, it is considered necessary to take steps that will support the personality development and socialization processes of those children growing up in disadvantageous conditions due to many reasons such as social exclusion, economic deficiencies and prejudice and it is thought that, while bringing the groups not reaching qualified education in the society, chorus education, directly or indirectly, will be an important and effective tool.

Based upon this thought, it has been planned to establish a music workshop involving Gypsy children in the primary school stage and including group music education towards the education of the children of this age group and prepared with this aim, the project named "Music Workshops for Gypsy Children" (ROCMA) with the no. OUAP 2015/16 accepted by Uludağ University Scientific Research Projects Unit has been put into practice in cooperation with Uludağ University and Federation of Bursa Central Gypsy Associations.

In the context of the project, with one pilot classroom each selected by first and fourth grades in a primary school which is located in Mustafakemalpaşa District of Bursa Province and the whole population of which consists of Gypsy children, two independent educators have performed their music studies as two course hours a week. 
In this study, in the process of chorus education performed within music workshop programme prepared with fourth grade students consisting of Gypsy children attending Güner Şen Pamukçu Primary School in Mustafakemalpaşa District of Bursa Province and defined as disadvantageous group, it has been aimed to identify various social, cultural and educational behaviour manners that they exhibit inside and outside of the classroom and to reveal the differentiation the students experience in the process following the provided education and depending upon the aim of the study, the following questions have been searched for an answer:

1) What are the contributions of the chorus activities performed within the context of Music Workshop programme to the social relationships and communicative skills of the students in the disadvantageous group?

2) What are the contributions of the chorus activities performed within the context of Music Workshop programme to the general education process of the students in the disadvantageous group?

3) What are the contributions of the chorus activities performed within the context of Music Workshop programme to the musical knowledge and skills of the students in the disadvantageous group?

4) What are the contributions of the performed chorus education to the cultural awareness of disadvantageous students?

5) What are the impacts and contributions of the participant observant to the application process?

\section{Method}

In this chapter, information related to the model of the research, the sample of it and obtaining data have been included.

\subsection{The Pattern of the Research}

Qualitative research method has been used in this study. Qualitative research is the interpretivist research approach based on observing multiple subjective data types and individuals in their own natural environment, being for revealing perception and events in a realistic and integrated way and preferred with regard to understanding researchers' emotions and cognition in a better way (Christensen, Johnson, \& A. Turner, 2015, p. 54; Yıldırım \& Şimşek, 2006, p. 39).

\subsection{The Group of the Study}

Restricted universe has been used in the study. Restricted universe is the one that can be reached. Studies are carried out over the restricted universe and their results are generalized only to this restricted universe. Gypsy children having education at Güner Şen Pamukçu Primary School in Mustafakemalpaşa District of Bursa Province in 2015-2016 academic year compose the universe of this study.

In the research, data have been obtained from the students of 4/A class of Güner Şen Pamukçu Primary School in Mustafakemalpaşa District of Bursa Province selected by using convenience sampling, one of the purposeful sampling methods. Convenience sampling, due to the researcher's choosing a close and easily accessible situation, brings the researcher in speed and practicality (Yıldırım \& Şimşek, 2006, p. 113).

In official records, in 4/A class, there are thirty-two students, nineteen of whom are girls (one of them is inclusive) and thirteen of whom are boys. Five students haven't attended the school for the year round and two students haven't attended the school for the second term. Demographic information regarding the students of 4/A class have been included in Table 1. Information in the table, on the grounds that they will not be handed in after they have been filled out by parents, has been presented to the researcher after having been filled out by the class teacher. In addition, it has been reached the information that the information of twelve students the demographic information of whom is not included in the table is not available in the teacher, either.

Table 1. 4/A class demographic information

\begin{tabular}{cccll}
\hline No & Year of Birth & Number of Siblings & Occupation (Father) & Occupation (Mother) \\
\hline 1 & 2006 & 3 & Artisan & Artisan \\
2 & 2007 & 3 & Artisan & Do Not Work \\
3 & 2007 & 3 & Junk Dealer & Do Not Work \\
4 & 2006 & 3 & Raising Livestock & Do Not Work \\
5 & 2005 & 3 & Junk Dealer & Do Not Work \\
\hline
\end{tabular}




\begin{tabular}{|c|c|c|c|c|}
\hline 6 & 2005 & - & Unemployed & Do Not Work \\
\hline 7 & 2004 & 5 & Raising Livestock & Do Not Work \\
\hline 8 & 2006 & 4 & Raising Livestock & Do Not Work \\
\hline 9 & 2007 & - & Unemployed & Do Not Work \\
\hline 10 & 2007 & 3 & Worker & Do Not Work \\
\hline 11 & 2005 & 2 & Junk Dealer & Workers \\
\hline 12 & 2006 & 2 & Stallholder & Do Not Work \\
\hline 13 & 2006 & 2 & Stallholder & Do Not Work \\
\hline 14 & 2007 & 4 & Artisan & Do Not Work \\
\hline 15 & 2006 & 3 & Worker & Do Not Work \\
\hline 16 & 2005 & 4 & Junk Dealer & Workers \\
\hline 17 & 2006 & 4 & Junk Dealer & Do Not Work \\
\hline 18 & 2007 & 3 & Worker & Do Not Work \\
\hline 19 & 2005 & 3 & Porter & Do Not Work \\
\hline 20 & 2006 & 3 & Porter & Do Not Work \\
\hline 21 & 2005 & 3 & Not Alive & Do Not Work \\
\hline 22 & 2006 & 2 & Raising Livestock & Do Not Work \\
\hline 23 & 2005 & 3 & Junk Dealer & Do Not Work \\
\hline 24 & 2005 & 4 & Stallholder & Do Not Work \\
\hline 25 & 2006 & 3 & Raising Livestock & Do Not Work \\
\hline
\end{tabular}

As seen in Table 1, ten of the students were born in 2006, six of them were born in 2007, eight of them were born in 2005 and one of them was born in 2004. Thirteen students have got three siblings, one student has got five siblings, four students have got two siblings, and five students have got four siblings. Again, considering the professions of the students' fathers, it is seen that three of them are artisans, six of them are junk dealers, three of them are stallholders, three of them are workers, two of them are porters, two of them are unemployed, five of them deal with raising livestock and the father of a child is not alive. However, it has been reached the information that two of the mothers are workers, one of them is an artisan and the other mothers do not work.

\subsection{Application}

All of the applications towards the research have been performed in Güner Şen Pamukçu Primary School in Mustafa Kemal District of Bursa Province. All of the students of the school in a neighbourhood consisting of Gypsy people are Gypsies. The school is rather old and needs maintenance. As there is no study hall appropriate for the necessities of the chorus education, all of the studies have been performed in 4/A class.

Studies have started in November in 2015/2016 academic year and have been performed on every Friday between 10:15-12:00. Keyboard has been brought to the classroom for the studies every week. In addition, for piano accompanied studies, piano accompanied records of the songs have been previously made and accompanied studies have been performed via amp.

\subsection{Data Collecting Tools}

With the aim of data collecting in the research, the following tools have been used:

- Children-family information form with the aim of reaching demographic information of children and family,

- Attendance list with the aim of determining the continuity of the participation in the study,

- Structured observation form with the aim of using it in the analysis of the video records regarding applications, 
- Social validity interview form used in the interviews with the teachers and the principals of the institute with the aim of determining the effect of the performed applications on the students and their opinions regarding the application,

- Reliability form among the observants with the aim of determining whether the video analyses regarding the applications have been recorded by the observant properly or not.

\subsection{Gathering and Analysing the Data}

Data have been gathered as participant observant in the natural environment of the study. Courses covered throughout an academic year with the aim of later performing the analysis of the data in a detailed way have been recorded with a video camera.

In this study, in addition to the participant observation, interviews have been made with the class teacher and the principals of the institute for social validity, the interviews made have been recorded and also, data have been simultaneously recorded into the semi-structured interview form. In semi-structured interviews, with the questions he/she has previously determined, the researcher can affect the flow of the interview depending upon the flow of the interview. The researcher gives the interviewee an opportunity to answer the questions in his/her own flexibility (Türnüklü, 2000, p. 547).

\subsection{The Analysis of the Data}

The analysis of the video recordings recorded through the activity has been performed within the framework of the common opinions of the participant observant and the other non-participant observant research team's member with the coding list formed according to the dimensions determined previously. Considering the determined categories and codes, with systematic analysis method, in the first month, the first video and the third video have been analysed, in the following months, the third video of each month has been analysed and in the last month, in addition to the third video, rehearsal and concert videos have been analysed. Systematic analysis is presented with a descriptive approach and themes and relations between themes are determined (Yildirım \& Şimşek, 2006, p. 224). The data obtained from this research have been split into categories, coded and interpreted by analysing.

\section{Results}

In this chapter, video analyses and results obtained from the interviews made have been included.

3.1 Regarding the Contribution of the Chorus Activities Performed within the Context of Music Workshop
Programme to the Social Relationships and Communicative Skills of the Students in the Disadvantageous Group

It has been observed that the communicative skills of the students are rather poor. It has been determined that they have difficulty in expressing themselves orally and that their speaking skills are poor. It has been observed that there is grouping both inside the classroom and outside of it and that the students, despite their being disadvantageous, isolate the more disadvantageous groups in themselves, do not sit with them and do not get in contact with them. The students of different gender do not want to sit together and see this as a shame. It has been seen that they have not been able to make progress in communicative skills following the process. It has been determined that from the third month, the situation of feeling discomfort with sitting together of the students of different gender has decreased but socio-economic exclusions have continued.

In the second term, with the start of concert preparations, it has been seen that there have been positive changes in the social relationships of the students attending the studies regularly such as studying together, being systematic and disciplined and adapting to the environment.

3.2 Results Regarding the Contribution of the Chorus Activities Performed within the Context of Music Workshop Programme to the General Education Process of the Students in the Disadvantageous Group

It has been seen that, especially with the second term, the number of students with perfect attendance in the classroom has decreased. In accordance with the information obtained from the interviews made with the principal of the institute and the class teacher, the information has been obtained that in spring months, especially in seasonal working period, students go out of town with their families and for that reason, absence increases. It has been determined that school-wide, course attendance has been rather low on Fridays but the attendance of the students in the group where chorus activities have been performed has been fairly high in proportion to the students in peer classrooms.

It has been seen that in getting in line, getting a command and adjusting themselves to these commands with the hand signs shown, the students have had great difficulty in terms of adapting, especially in the first two months; 
in the following months, they have applied the commands more easily; they have acquired the property of repeating the commands given especially in the studies of the last two months with the group.

However, it has been determined that they have had great difficulty in acting with the group in the first months and in the following months, they have acquired the property of acting together. In addition, with the start of the concert studies, it has been determined that students' senses of belonging and motivations have made progress in a positive way.

3.3 Results Regarding the Contribution of the Chorus Activities Performed within the Context of Music Workshop Programme to the Musical Knowledge and Skills of the Students in the Disadvantageous Group

\subsubsection{Body Softness and Comfort}

In the first weeks of the study, body comfort and softening studies, breathing games, pastiche studies and studies of rhythm with lyrics have been performed and it has been observed that students have been eager to perform the studies. Yet, especially in the first months, it has been determined that they have had difficulty in acting together in accordance with the commands given in these studies, and generally all of the students have had adaptation difficulty in starting and finishing the exercises together. From the third month, it has been seen that they have more easily adapted to the commands given related to these studies.

\subsubsection{Rhythm Studies}

From the first month, the studies of one-word beat and rhythm with lyrics have been started and in the third month, two-word beat and rhythm with lyrics have been added. It has been seen that the students have performed the studies of one-word beat and rhythm with lyrics at a good level in individual and group works. Considering the readiness levels, the studies of three-word beat and rhythm with lyrics have been started with the second term and it has been determined that only three students have been able to perform these studies individually and togetherness have not been provided.

\subsubsection{Audince Studies}

Along with two-word beat and rhythm studies, audince education with one-note have been started to perform and it has been seen that all of the students have had difficulty in repeating the sound rising from the keyboard. With the second term, two-note audince studies have been started. Yet, it has been determined that only three students have become successful in two-note repeating. As for three-note audince studies, none of the students have been able to achieve success.

\subsubsection{Voice Training Studies}

Within the context of voice training studies, primarily from the first month, the studies of legato in rising tones have been started to perform. It has been determined that, in the beginning of the studies, the students have had difficulty in repeating the melody and starting and finishing music phrases together, in the second month, they have started to sing the melodies they hear in a cleaner way generally and with the start of one-note and two-note audince studies, they have sung the melody repetitions in a clean way.

With the voice training studies, pre-determined nursery rhymes have been started to train with the teaching by ear method. Yet, it has been determined that two of the students are completely illiterate and the others do not have a fluent reading and writing skill. For that reason, the studies have followed a slower course than anticipated. It has been determined that although the students have had troubles with literacy, they have had great pleasure at singing the songs in different languages but they have had trouble with the pronunciation.

It has been seen that the students have enjoyed vocalizing especially ballad arrangements and moving songs. It has been seen that although chorus courses have been performed with keyboard and for that reason, they have not been unfamiliar with the sound of the keyboard, they have had difficulty in piano-accompanied vocalizing the songs in the beginning but they have enjoyed accompanied studying and in the following studies, the great majority of the classroom has acquired the piano-accompanied singing skill. However, it has been determined that all of the students have had great pleasure at singing with the group.

It has been determined that the students have not been able to become successful in tone studies and they have not been able to apply the tones in the songs either, they have acquired trolling as a habit and trolling habit of the majority of the students have not shown a great alteration in a positive way. 


\subsection{Results Regarding the Contribution of the Performed Chorus Education to the Cultural Awareness of the Disadvantageous Students}

It has been seen that the students in this group that have not encountered the samples of educational music in their previous educations have had pleasure at vocalizing ballad arrangements belonging to our national music genres and the music genres belonging to different cultures.

In addition, in consideration of the results obtained from the interview made with the class teacher and the participant observant, it has been determined that the families of some students have been asked for their children's not participating in a concert not including Gypsy music in an event where Gypsy audiences are, but the students have been eager to participate in the concert and exhibit the performed studies and in the rehearsals for the concert and concert event, they have acted with the common musical behaviour and values.

\subsection{Results Regarding the Impact and Contribution of the Participant Observant to the Application Process}

It has been determined that the students' relations with the teacher of chorus course running the studies as the participant observant have been positive, the students have made an effort to apply the instructions of the teacher and the teacher's using keyboard during the course have affected the motivation of the students towards the course positively.

In addition, the participant observant's having defined a target for the students in the beginning of the year and having shared his/her targets with the students as well and having tried to enable them to feel important as a chorist have increased the motivations of the students towards the chorus studies to the high level and this situation have affected the continuity of the course attendance positively. However, from the interviews made with the institute principal and the class teacher, it has been determined that students' becoming a part of the project have led them to feel themselves more important in the peer groups.

\section{Discussion}

Conclusions obtained from the research were discussed in this section and some recommendations were created as follows:

The place of the Gypsy children in the social structure must not be ignored, continuity in the compulsory education process and their completing this education process in the same conditions with the other members of the society in a good way must be provided.

It is seen that generally, Gypsy families do not attach due importance to their children's formal education and accordingly, their children do not have any expectations from the education and their education is left half-finished due to many reasons such as early marriage. Facing with poverty and deprivation, Gypsy children's getting the most out of rights to education must be provided, education policies must be arranged towards the continuity of their education and by providing aforementioned children and their families with good guidance services, the increase of their awareness of continuing education must be provided.

It is highly important that the Gypsy children in the disadvantageous groups be presented with the opportunities with which they can reveal their talents and turn the music continuously existing in their daily lives into an advantage in educational terms. With this aim, in the general education process, it is considered necessary that music education, especially chorus education, be attached particular importance. Because chorus education performed within the context of general music education introduces the child to the qualified music education in a short time, brings the child in the responsibility of working individually and collectively and provides considerable contributions to his/her acquiring collective working order and discipline and socializing process.

Music is considered as one of the strongest social ties in the society. For a nation to integrate, vocal unity in that community is needed. For that reason, choruses are among the most important communities that enable the unity and solidarity to reach high levels and reinforce them (Yener, 2001, p. 85). With the aim of gaining a seat in the society, not being excluded and integrating of Gypsies, having a considerable population in Turkey, it is considered necessary that music, with its uniting aspect, gain a privileged seat in the educations of Gypsy children. With this aim, considered as their strong sides in every step of their compulsory education, Gypsy children's music education must be performed by the domain experts and considered as having an efficient role in their social and cultural formation, chorus education must be enabled to be always involved in the music education process. 


\section{References}

Akkan, B. E., Deniz, M. D., \& Ertan, M. (2016). Yoksulluğun ve Sosyal Dışlanmanın Romanlaşması [The Gypsy of Poverty and Social Exclusion]. In B. Altınbaş içinde (Ed.), Dezavantajll Gruplar ve Sosyal Politika (ss. 115-135). İstanbul: Nobel Yayıncılık.

Akkan, B., Deniz, M., \& Ertan, M. (2011). Sosyal Dışlanmanın Roman Halleri [Gypsy Situations of Social Exclusion]. İstanbul: Punto Baskı Çözümleri.

Alp, L. (2014). Dezavantajlı Grupların İstihdama Katılmalart: G20 Ülkelerindeki Başarll Uygulamalar [Participation of Disadvantaged Groups in Employment: Successful Implementations in the G20 Countries]. Ankara: T.C.Çalışma ve Sosyal Güvenlik Bakanlığı Dış İlişkiler ve Yurtdışı İşçi Hizmetleri Genel Müdürlüğ̈̈, Yayımlanmamış Yüksek Lisans Tezi.

Apaydın, M. (2001). Koro ile Müzik Eğitiminin Toplumun Müziksel Düzeyini Geliştirmedeki Yeri ve Önemi [The Place and Advancement of Music Education with the Choir in Developing the Musical Level of Society]. In I. Ulusal Koro Eğitimi ve Yönetimi Sempozyumu (ss. 131-140). Ankara: Rekmay Ltd. Şti.

Barry, B. (1998). Social Exclusion, Social Isolation and the Distribution of Income. London School of Economics and Political Science STICERD Research Paper Series. Retrieved from https://papers.ssrn.com/sol3/papers.cfm?abstract_id=1158903 adresinden alındı

Cevizci, S. et al. (2015). Dezavantajlı öğrencilerde sağlık algısının ve psikososyal becerilerin geliştirilmesi: Okul tabanlı bir müdahale çalışması [Development of Health Perception and Psychosocial Skills in Disadvantaged Students: A School-Based İntervention Study]. TAF Preventive Medicine Bulletin, 14(1), 39-48. https://doi.org/10.5455/pmb.1-1394612857

Chakravarty, S. R. (2006). The Measurement of Social Exclusion. Review of Income and Wealth, 52(3), 377-398. https://doi.org/10.1111/j.1475-4991.2006.00195.x

Christensen, L. B., Johnson, R., \& A. Turner, L. (2015). Araşttrma Yöntemleri [Research Methods]. Ankara: Anı Yayincilik.

Çevik, S. (2001). Koro Eğitimi Sürecinde Repertuvar Oluşturma ve Konser Programları Hazırlamada Yeni Yaklaşımlar [Preparation of Repertory in the Process of Choir Education and New Approaches in Preparing Concert Programs]. In I. Ulusal Koro Eğitimi ve Yönetimi Sempozyumu (ss. 67-76). Ankara: Rekmay Ltd. Şti.

Egüz, S. (1981). Koro Eğitimi ve Yönetimi [Choir education and Conducting]. Ankara: Ayyıldız Matbaası.

Genç, Y., Taylan, H., \& Barış, İ. (2015). Roman Çocuklarının Eğitim Süreci ve Akademik Başarılarında Sosyal Dışlanma Algısının Rolü [The Perception Of Social Exclusion And Its Role On The Process Of Education and Academic Achivement of Romani Children]. The Journal of Academic Social Science Studies, 33, 79-97. https://doi.org/10.9761/JASSS2796

Hekimler, G. (2012). Yoksulluk Mu Yoksunluk Mu? Sosyal Dişlanma Üzerine Bir Değerlendirme [Is This Poverty or Deprivation: An Assessment on Social Exclusion]. Tekirdağ S.M.M.M Odası Sosyal Bilimler Dergisi, 1, 1-28.

Kılınçer, Z., \& Mustan Dönmez, B. (2013). "Kültürel Kimlik" ve "Kültürel Adaptasyon" Kavramları Çerçevesinde Malatya Romanlarının Müzik Pratikleri [Music Practices of Malatya Romanies on the Concepts of "Cultural Identity" and "Cultural Adaptation"]. Folklor/Edebiyat, 19(74), 9-45.

Klasen, S. (2016). Social Exclusion, Children, and Education: Conceptual and Measurement Issues. Retrieved from http://www.oecd.org/education/school/1855901.pdf adresinden alındı

Sağer, T., \& Mustan Dönmez, B. (2012). Batı-Dış1 Müzik Eğitimi Yöntemleri Müzik Eğitimi Disiplinine Ne Kazandırılabilir? "Roman Müzik Eğitimi Örnek Durumu" Üzererine Kültürel ve Pedagojik Bir Analiz [Non-Western Methods of Music Training What Can We Bring into the Discipline of Music Training? A Cultural and Pedagogical Analysis on the "Case of Romanian Musical Training"]. Akademik Bakış Dergisi, $33,1-14$.

Sökezoğlu, D. (2012). Gönüllü Konservatuvar Öğrencilerinin İlköğretim Okullarında Yaptıkları Koro Çalışmalarının Müzik Öğretmenliği Algılarına Etkileri [Effects of Volunteer Conservatory Students "Elementary Schools on the Perception of Music Teachers" Choir Studies]. In III. Uluslararası Hisarl Ahmet Seтроzуити (ss. 258-267). Kütahya: Ekspres Matbaası. 
Şener, C. (2006). Türkiye'de Yaşayan Etnik ve Dinsel Gruplar [Ethnic and Religious Groups in Turkey]. İstanbul: Etik Yayınları.

Taylan, H. H., \& Barış, İ. (2015). Romanlar ve Sosyal Dışlanma [Romanies and Social Exclusion]. Konya: Çizgi Kitabevi.

Türkmen, E. F. (2012). Çocuk Korolarına Katılımın Çocukların İşitsel Algılarına Etkilerinin Değerlendirilmesi [Assessment of the Effects of Participation in Child Choir on Children's Auditory Perceptions]. In II. Uluslararası Hisarl Ahmet Sempozyumu (ss. 276-286). Kütahya: Ekspres Matbaası.

Türnüklü, A. (2000). Eğitimbilim Araştırmalarında Etkin Olarak Kullanılabilecek Nitel Bir Araştırma Tekniği: Görüşme [A Qualitative Research Technique to be Effectively Used in Educational Research: Interview]. Kuram ve Uygulamda Ĕ̈itim Yönetimi Dergisi, 543-559.

Uçan, A. (2001). İnsan, Müzik, Koro Eğitimi ve Koro Eğitiminin Temelleri [Fundamentals of Human, Music, Choir Education and Choir Education]. In I. Ulusal Koro Eğitimi ve Yönetimi Sempozyumu (ss. 7-56). Ankara: Rekmay Ltd. Şti.

Uzpeder, E., Danova/Roussinova, S., Özçelik, S., \& Gökçen, S. (2008). Biz Buradayız!: Türkiye'de Romanlar, Ayrımc Uygulamalar ve Hak Mücadelesi [We Are Here!: Romanies in Turkey, Discriminatory Practices and Right Struggle]. İstanbul: Mart Matbaacılık Sanatları Tic. ve San. Ltd.Şti.

Ünaldı, H. (2012). Türkiye'de Yaşayan Kültürel Bir Farklılık: Çingeneler [A Cultural Difference Living in Turkey: Romanies]. Batman Üniversitesi Yaşam Bilimleri Dergisi, 1(1), 615-626.

Yener, S. (2001). Türkiye'deki Koro Çeşitleri ve Müzik Toplum Etkileşiminde Koro Müziğinin Rolü [The Role of Choral Music in the Interaction of Choir Variety and Music Society in Turkey]. In I. Ulusal Koro Eğitimi ve Yönetimi Sempozyumu (ss. 83-93). Ankara: Sevda-Cenap And Müzik Vakfi.

Yıldırım, A., \& Şimşek, H. (2006). Sosyal Bilimlerde Nitel Araştırma Yöntemleri [Qualitative Research Methods in the Social Sciences]. Ankara: Seçkin Yayınc1lık.

\section{Copyrights}

Copyright for this article is retained by the author(s), with first publication rights granted to the journal.

This is an open-access article distributed under the terms and conditions of the Creative Commons Attribution license (http://creativecommons.org/licenses/by/4.0/). 